\title{
Ocena skutków regulacji poselskiego projektu ustawy o zmianie ustawy o samorządzie gminnym ${ }^{1}$
}

Celem projektu jest takie ukształtowanie procedury zmiany granic gmin, aby zawierała ona skuteczny mechanizm kontroli społecznej tego procesu. Zdaniem autorki opinii nie ma pewności, czy w procedurze zmiany granic gmin proponowanej przez wnioskodawców zostaną całkowicie wyeliminowane sytuacje konfliktowe. Proponowane regulacje koncentrują się bowiem na ochronie gmin objętych możliwością zmiany granic przed zmianami terytorialnymi dokonywanymi mimo braku ich zgody. Autorka podkreśla, że rozwiązaniem, które porównywalnie chroniłoby interesy zarówno gminy występującej z wnioskiem o zmianę granic, jak i gminy objętej tym wnioskiem, byłoby dopuszczenie do zmian terytorialnych wyłącznie pod warunkiem zawarcia porozumienia między stronami.

Słowa kluczowe: gmina, ocena skutków regulacji, projekt ustawy, samorząd gminny

Impact assessment of the Deputies' Bill on Amendingthe Act on Municipal Self-Government: The aim of the bill is to shape the procedure of changing the boundaries of municipalities in such a way, that it includes an effective mechanism of social control of this process. According to the author, it is not certain whether conflict situations will be completely eliminated within the framework of the procedure of changing the boundaries of communes proposed by the sponsors of the bill. The proposed regulations are focused on the protection of municipalities covered by the possibility of changing borders from territorial changes made despite the lack of their consent. The author stresses that a solution which would protect the interests of both the municipality applying for the change of borders and the municipality covered by the application would be to allow territorial changes only on condition that an agreement between the parties is concluded.

Keywords: municipality, impact assessment, bill, municipal self-government

Ekspert ds. finansów publicznych BAS - monika.korolewska@sejm.gov.pl • https://orcid.org/0000-0002-6802-2367

\section{Zakres przedmiotowy ustawy}

Projekt ustawy przewiduje zmianę przepisów ustawy z 8 marca 1990 r. o samorządzie gminnym (t.j. Dz.U. 2019, poz. 506; dalej: u.s.g.) określających procedurę zmian terytorialnych dotyczących gmin.

Proponowane przez wnioskodawców nowe brzmienie art. 4b u.s.g. ma skutkować:

1 Ocena skutków regulacji poselskiego projektu ustawy o zmianie ustawy o samorządzie gminnym (druk sejmowy nr 3414) sporządzona 3 października 2019 r. na zlecenie zastępcy Szefa Kancelarii Sejmu; BAS-WASiE 593/19. 
- możliwością wydania przez Radę Ministrów rozporządzenia w sprawie utworzenia, połączenia, podziału i zniesienia gminy oraz ustalenia granic gminy na wniosek rady gminy wyłącznie w sytuacji pozytywnych opinii rad gmin objętych wnioskiem, poprzedzonych przeprowadzeniem przez te rady konsultacji z mieszkańcami,

- odstąpieniem od konsultacji z mieszkańcami w przypadku przeprowadzenia referendum lokalnego w sprawie utworzenia, połączenia, podziału i zniesienia gminy oraz ustalenia granic gminy,

- zwolnieniem rady gminy z powinności przedstawienia opinii, jeśli referendum lokalne w sprawie utworzenia, połączenia, podziału i zniesienia gminy oraz ustalenia granic gminy jest ważne ${ }^{2} \mathrm{w}$ rozumieniu przepisu art. 55 ust. 1 ustawy z 15 września 2000 r. o referendum lokalnym, t.j. Dz.U. 2019, poz. 741,

- uznaniem wyniku referendum za pozytywną opinię rady gminy, w przypadku gdy w referendum za zaproponowanymi zmianami oddanych zostanie więcej niż połowa ważnych głosów,

- uznaniem wyniku referendum za negatywną opinię rady gminy, w przypadku gdy w referendum za zaproponowanymi zmianami nie zostanie oddanych więcej niż połowa ważnych głosów,

- domniemaniem wyrażenia opinii negatywnej przez radę gminy, w przypadku niewyrażenia opinii przez radę w terminie trzech miesięcy od dnia otrzymania wystąpienia o opinię.

Wnioskodawcy proponują ponadto wprowadzić zmianę do art. 4 ust. 5 u.s.g. (art. 1 pkt 1 projektu), zgodnie z którą zmiany granic gmin przeprowadzane na wniosek rady gminy będą następować z dniem 1 stycznia roku następującego po roku, w którym rozpoczęła swoją kadencję rada gminy. W ocenie wnioskodawców taka zmiana wymusi ograniczenie możliwej częstotliwości zmian granic gmin inicjowanych na wniosek rady gminy oraz wprowadzi pewne uporządkowanie do całego procesu, który będzie wywierał skutki dopiero od nowej kadencji rady gminy, a nie jeszcze w czasie jej trwania.

\section{Podmioty, na które oddziałuje akt}

Projekt dotyczy:

- gmin,

- Rady Ministrów - w związku z uprawnieniem do regulowania granic gmin $\mathrm{w}$ formie rozporządzenia oraz

- lokalnych społeczności.

2 Jeżeli wzięło w nim udział co najmniej 30\% uprawnionych do głosowania. 


\section{Celowość wprowadzenia aktu}

Zasadniczym celem projektu ustawy jest wprowadzenie skutecznego mechanizmu kontroli społecznej w stosunku do procedury zmiany granic gmin, w przypadku kiedy zmiany inicjowane są na wniosek rady gminy. Wnioskodawcy podkreślają, że: [k]onieczność wprowadzenia takiego mechanizmu uwidoczniła się w przypadku sprawy powiększenia miasta Opola. Wtedy to głos mieszkańców przy podejmowaniu decyzji dotyczacej zmiany granic czterech gmin (Dobrzeń Wielki, Dąbrowa, Prószków, Komprachcice) nie został wysłuchany, chociaż wyniki konsultacji społecznych w sposób jednoznaczny wskazywały na to, że mieszkańcy nie wyrażaja zgody na zmiane granic ${ }^{3}$.

Należy zauważyć, że przywołany przez wnioskodawców projektu sprzeciw jednostek samorządu terytorialnego wobec zmian terytorialnych odbił się szerokim echem. Znalazł on swój wyraz w dyskusji publicznej, w toku której formułowany był postulat nowego uregulowania przepisów dotyczących zmian granic administracyjnych gmin. Warto zwrócić uwagę w tym kontekście na opinię Związku Gmin Wiejskich RP, który opowiada się za zmianą ustawy o samorządzie gminnym i przepisów wykonawczych odnoszących się do zmian granic gmin. Związek zapowiadał nawet przygotowanie własnego projektu ustawy w tej sprawie, który zwiększałby uprawnienia gmin tracących - w wyniku zmian granic - część swego terytorium i majątku m.in. przez przyznanie gminom prawa do odszkodowania $\mathrm{z}$ tego tytułu i odwołania się do sądu od decyzji zmieniającej granice gmin. Przedstawiciele Związku wskazywali również na konieczność precyzyjnego uregulowania przesłanek pozwalających na wszczęcie procesów przemianowych, akcentując, że: zgoda mieszkańców powinna być wyrażona większym wspótuczestnictwem gmin, a wyniki konsultacji powinny być oparte na przepisach o referendach lokalnych ${ }^{4}$. Z inicjatywy Związku funkcjonowanie art. 4 u.s.g. w praktyce gmin wiejskich było również tematem posiedzenia sejmowej Komisji Samorządu Terytorialnego i Polityki Regionalnej5. Ponadto Parlamentarny Zespół ds. Obrony Polskiej Samorządności wystosował dezyderat do Prezesa Rady Ministrów w sprawie zmiany granic gmin na przykładzie powiększenia miasta Opola uchwalony na posiedzeniu Zespołu w dniu 6 kwietnia 2017 r.

W toku debaty parlamentarnej poświęconej dokonywaniu zmian granic gmin przedstawiciel Ministerstwa Spraw Wewnętrznych i Administracji zauważył, że

3 Zob. uzasadnienie do poselskiego projektu ustawy o zmianie ustawy o samorządzie gminnym, druk sejmowy nr 3414/VIII kad., s. 1.

$4 \quad$ K. Kubicka-Żac, Gminy wiejskie oczekuja uregulowania zasad przejmowania ich przez miasta, https://www.prawo.pl/samorzad/zmiana-granic-gmin-i-ustalenie-kwestii-majatkowych-konieczne,374415.html.

5 Zob. pełny zapis przebiegu posiedzenia Komisji Samorządu Terytorialnego i Polityki Regionalnej - Posiedzenie (nr 270) z 20 lutego 2019 r., http://orka.sejm.gov.pl/zapisy8. nsf/0/8770CD9BCC620F84C12583C5005146EF/\%24File/0402508.pdf. 
w ujęciu historycznym od początku tworzenia samorządu można doliczyć się około 500 procesów zmiany granic. W praktyce większość z nich nie miała jednak charakteru spornego, a zmiany granic były popierane przez wszystkie jednostki samorządu terytorialnego, między którymi toczyła się sprawa zmiany granic ${ }^{6}$. Jakkolwiek nie można odmówić racji tej uwadze, to jednocześnie trzeba pamiętać, że zdarzają się przypadki sprzeciwu gmin, których obszary są przyłączane do innej gminy w wyniku zmian terytorialnych. Świadczą o tym nie tylko przekazy medialne, ale również wielokrotne zaskarżanie do Trybunału Konstytucyjnego przepisów stanowiących podstawę prawną dokonywania zmian terytorialnych jednostek samorządu terytorialnego ${ }^{7}$. Właśnie z uwagi na liczbę wniosków wniesionych do Trybunału Konstytucyjnego przez jednostki samorządu terytorialnego w związku z dokonywanymi zmianami w podziale terytorialnym Trybunał

6 Zob. wypowiedź dyrektora Departamentu Administracji Publicznej w Ministerstwie Spraw Wewnętrznych i Administracji na posiedzeniu Komisji Samorządu Terytorialnego i Polityki Regionalnej (nr 270) w dniu 20 lutego 2019 r.

7 Na przykład:

- Rada Gminy Stare Miasto wystąpiła o zbadanie zgodności z Konstytucją $\$ 2$ rozporządzenia Rady Ministrów z 24 lipca 2017 r. w sprawie ustalenia granic niektórych gmin i miast, nadania niektórym miejscowościom statusu miasta, zmiany nazwy gminy oraz siedzib władz niektórych gmin (Dz.U. poz. 1427), w zakresie zmiany granicy między gminami Stare Miasto i miastem na prawach powiatu Koninem, polegającej na włączeniu do dotychczasowego obszaru miasta na prawach powiatu Konin części obszaru obrębu ewidencyjnego Rumin - sygn. akt U 1/19,

- Rada Powiatu Opolskiego, Rada Gminy Dobrzeń Wielki, Rada Gminy Komprachcice, Rada Miejska w Prószkowie oraz Rada Gminy Dąbrowa wystąpiły z wnioskiem o stwierdzenie niezgodności z Konstytucją odpowiednio $\$ 1$ pkt 2 , $\$ 1$ pkt 2 lit. a, $\$ 1$ pkt 2 lit. b, $\$ 1$ pkt 2 lit. c, $\$ 1$ pkt 2 lit. d rozporządzenia Rady Ministrów z 19 lipca 2016 r. w sprawie ustalenia granic niektórych gmin i miast, nadania niektórym miejscowościom statusu miasta oraz zmiany nazwy gminy (Dz.U. poz. 1134) - sygn. akt U 2/16, OTK-A ZU 2017, poz. 4,

- Rada Gminy Brzeźnica wnioskowała o kontrolę konstytucyjności $\$ 1$ pkt 1 lit. b rozporządzenia Rady Ministrów z 26 lipca 2005 r. w sprawie ustalenia granic niektórych gmin i miast oraz nadania miejscowościom statusu miasta (Dz.U. nr 141, poz. 1185, ze zm.), który wprowadził zmianę granic między gminami Brzeźnica w powiecie wadowickim i Czernichów w powiecie krakowskim - sygn. akt U 9/07, OTK-A ZU 2009, poz. 152.

Rozporządzenia w sprawie ustalenia lub zmiany granic jednostek samorządu terytorialnego były również przedmiotem merytorycznej oceny Trybunału Konstytucyjnego m.in. w wyrokach z: 25 marca 2003 r., sygn. akt U 10/01, OTK-A ZU 2003, nr 3, poz. 23; 4 listopada 2003 r., sygn. akt K 1/03, OTK-A ZU 2003, nr 8, poz. 85; 1 czerwca 2004 r., sygn. akt U 2/03, OTK-A ZU 2004, nr 6, poz. 54; 18 lipca 2006 r., sygn. akt U 5/04, OTK-A ZU 2006, nr 7, poz. 80; 5 grudnia 2006 r., sygn. akt U 2/06, OTK-A ZU 2006, nr 11, poz. 168. 
zwrócił uwagę, że przyjęty przez ustawodawcę mechanizm nie spełnia oczekiwań podmiotów biorących udział $\mathrm{w}$ tym procesie. $\mathrm{W}$ ocenie Trybunału zarówno to zjawisko, jak i wątpliwości przedstawicieli doktryny prawnej wskazują na pewne nieprawidłowości wynikające bądź z samych przepisów, bądź ze sposobu ich stosowania ${ }^{8}$. W związku $\mathrm{z}$ tym wyrokiem Trybunał Konstytucyjny postanowił w trybie art. 4 ust. 2 ustawy z 1 sierpnia 1997 r. o Trybunale Konstytucyjnym ${ }^{9}$ zasygnalizować Sejmowi potrzebę stworzenia skutecznych mechanizmów prawnych zabezpieczających jednostki samorządu terytorialnego przed pochopnymi zmianami ich granic ${ }^{10}$. W postanowieniu tym Trybunał stwierdził, że rozwiązania prawne dotyczące zmian granic jednostek samorządu terytorialnego mogą budzić wątpliwości, a fakt, iż sposób ich stosowania wywołuje protesty tych jednostek, może wskazywać na potrzebę wypracowania lepszego modelu zmian terytorialnych.

Można zatem stwierdzić, że propozycja zmiany przepisów określających procedurę związaną ze zmianami terytorialnymi gmin zarówno wpisuje się w doktrynę prawną, jak i przystaje do postulatu wysuwanego w debatach publicznych toczących się przy okazji zmian granic gmin. Projektowane przepisy są zwłaszcza zbieżne z niektórymi postulatami wysuwanymi w tym kontekście przez część środowiska samorządowego, w szczególności tego reprezentującego interesy niewielkich jednostek samorządu terytorialnego, wśród których sposób stosowania obecnych rozwiązań prawnych dotyczących zmian granic wywołuje największe protesty.

\section{Planowane środki (narzędzia i działania) realizacji celów}

Wnioskodawcy proponują w ustawie o samorządzie gminnym dokonać zmian w zapisach odnoszących się do trybu zmiany granic gmin inicjowanego na wniosek zainteresowanej rady gminy. Celem tych zmian jest wprowadzenie do systemu prawa norm zabezpieczających gminy objęte wnioskiem o przeprowadzenie zmiany granic, w przypadku gdy z propozycją zmiany terytorialnej gminy występuje rada gminy.

Zgodnie z obowiązującymi regulacjami prawem do tworzenia, łączenia, dzielenia i znoszenia gmin oraz ustalania ich granic dysponuje Rada Ministrów. Decyzje $\mathrm{w}$ tych sprawach Rada Ministrów podejmuje w drodze rozporządzenia,

8 Zob. wyrok TK z 8 kwietnia 2009 r., sygn. akt K 37/06, OTK-A ZU 2009, nr 4, poz. 47.

9 Zgodnie z tym przepisem Trybunał przedstawiał właściwym organom stanowiącym prawo uwagi o stwierdzonych uchybieniach i lukach w prawie, których usunięcie jest niezbędne dla zapewnienia spójności systemu prawnego Rzeczypospolitej Polskiej.

10 Zob. postanowienie TK z 12 maja 2009 r., sygn. akt S 3/09, OTK-A ZU 2009, nr 5, poz. 75 . 
które może być wydane także na wniosek zainteresowanych rad gmin (art. 4 ust. 1 i 2 u.s.g.). Przepisem ustawowym, który reguluje przypadki wydawania rozporządzeń w sprawie zmian terytorialnych na wniosek rad gmin, jest art. 4b u.s.g. Wynika z niego, że wydanie rozporządzenia w sprawach tworzenia, łączenia, dzielenia i znoszenia gmin oraz ustalania ich granic na wniosek rady gminy wymaga:

- wniosku rady gminy poprzedzonego przeprowadzeniem przez tę radę konsultacji z mieszkańcami, wraz z uzasadnieniem oraz niezbędnymi dokumentami, mapami i informacjami potwierdzającymi zasadność wniosku,

- opinii rad gmin objętych wnioskiem, poprzedzonych przeprowadzeniem przez te rady konsultacji z mieszkańcami, a w przypadku zmiany granic gminy naruszającej granice powiatów lub województw - opinii odpowiednich rad powiatów lub sejmików województw,

- opinii wojewody właściwego dla gminy lub gmin objętych wnioskiem.

Rady gmin mogą ograniczyć konsultacje jedynie do mieszkańców jednostki pomocniczej gminy objętej zmianą (art. 4 b ust. 2 w związku $\mathrm{z}$ art. 4 a ust. 2 u.s.g.).

Przepisy zezwalają na uznanie za spełniony wymóg zasięgnięcia opinii właściwych rad gmin $z$ upływem trzech miesięcy od dnia otrzymania przez nie wystąpienia rady gminy wnioskującej o opinię w sprawie zmiany granic (art. 4b ust. 2 w związku $\mathrm{z}$ art. 4 a ust. 3 u.s.g.).

Rada gminy będąca wnioskodawcą składa wniosek w sprawach tworzenia, łączenia, dzielenia i znoszenia gmin oraz ustalania ich granic do ministra właściwego do spraw administracji publicznej, za pośrednictwem wojewody właściwego ze względu na siedzibę wnioskodawcy. Termin składania wniosków ustalono na dzień 31 marca. Szczegółowe wymagania, jakim powinien odpowiadać wniosek rady gminy oraz tryb jego składania i rozpatrywania, określa rozporządzenie Rady Ministrów z 9 sierpnia 2001 r. w sprawie trybu postępowania przy składaniu wniosków dotyczących tworzenia, łączenia, dzielenia, znoszenia i ustalania granic gmin, nadawania gminie lub miejscowości statusu miasta, ustalania i zmiany nazw gmin i siedzib ich władz oraz dokumentów wymaganych w tych sprawach.

Ustalenie i zmiana granic gmin powinny przebiegać w sposób zapewniający gminie terytorium możliwie jednorodne ze względu na układ osadniczy i przestrzenny, uwzględniający więzi społeczne, gospodarcze i kulturowe oraz zapewniający zdolność wykonywania zadań publicznych (ust. $3 \mathrm{w}$ art. 4 u.s.g.).

W sprawie utworzenia, połączenia, podziału i zniesienia gminy oraz ustalenia granic gminy może być przeprowadzone referendum lokalne. $\mathrm{Z}$ inicjatywą przeprowadzenia takiego referendum może wystąpić jedynie grupa co najmniej 15 obywateli, o której mowa w art. 11 ust. 1a ustawy z 15 września 2000 r. o referendum lokalnym. Pytanie referendalne powinno określać szczegółowo proponowane zmiany w podziale terytorialnym państwa. Referendum nie przeprowa- 
dza się, jeżeli z analizy przeprowadzonej przed referendum wynika, że na skutek podziału lub ustalenia nowych granic gminy:

- dochody podatkowe na mieszkańca gminy w zmienionych granicach lub gminy utworzonej byłyby niższe od najniższych dochodów podatkowych na mieszkańca ustalonych dla poszczególnych gmin zgodnie z ustawą z 13 listopada 2003 r. o dochodach jednostek samorządu terytorialnego,

- gmina w zmienionych granicach lub gmina utworzona byłaby mniejsza od najmniejszej pod względem liczby mieszkańców gminy w Polsce według stanu na dzień 31 grudnia roku poprzedzającego ogłoszenie rozporządzenia $\mathrm{w}$ sprawie szeroko pojętych zmian terytorialnych wskazanych $\mathrm{w}$ art. 4 u.s.g. (art. 4c u.s.g.).

Powyższe negatywne przesłanki blokują również możliwość wydania przez Radę Ministrów rozporządzenia w sprawach tworzenia, łączenia, dzielenia i znoszenia gmin oraz ustalania ich granic (art. 4 d u.s.g.).

Wnioskodawcy proponują dokonanie zmian w powyższej procedurze przede wszystkim przez:

- związanie Rady Ministrów w zakresie przeprowadzenia zmian terytorialnych wyrażeniem zgody na ten proces przez gminy objęte wnioskiem o zmianę granic,

- nadanie referendum lokalnemu w sprawie utworzenia, połączenia, podziału i zniesienia gminy oraz ustalenia granic gminy charakteru rozstrzygającego dzięki związaniu rady gminy w zakresie treści sporządzanej przez nią opinii wynikiem ważnego referendum,

- ustanowienie domniemania wyrażenia negatywnej opinii w przypadku niewyrażenia opinii w terminie trzech miesięcy od dnia otrzymania wystąpienia o opinię.

Należy zauważyć, że Trybunał Konstytucyjny wielokrotnie wypowiadał się $\mathrm{w}$ sprawie procedury zmiany granic gmin dokonywanej na wniosek zainteresowanej rady, wyrażając pogląd co do merytorycznej zgodności uregulowań w tym zakresie z przepisami konstytucyjnymi. Jakkolwiek w wyroku z 8 kwietnia $2009 \mathrm{r}$. (sygn. akt K 37/06) Trybunał odszedł od tezy o dopuszczalności badania rozporządzeń w sprawie ustalania lub zmiany granic jednostek samorządu terytorialnego, uznając, że w odniesieniu do tych rozporządzeń ocena konstytucyjności łączy się w większym stopniu z oceną faktów niż z oceną obowiązujących norm ${ }^{11}$.

11 Rozporzadzenia dokonujace zmian granic jednostek samorządu terytorialnego maja szczególny charakter. [...] Mamy bowiem do czynienia z rozporządzeniami określanymi $w$ doktrynie jako „rozporządzenia” różniace się od rozporządzeń „klasycznych”, przewidzianych $w$ art. 87 i art. 92 Konstytucji. Owe „rozporządzenia” różnią się od rozporzadzeń „klasycznych” tym, że sensem ich wydania nie jest ustanowienie norm 
Jednak regulacje, które stanowiły punkt odniesienia do kontroli przez Trybunał Konstytucyjny zgodności z prawem zasad zmiany granic gmin przed tym wyrokiem, zachowują swoją adekwatność także w obowiązującym stanie prawnym oraz w odniesieniu do proponowanych zmian legislacyjnych. Stąd w kontekście oceny środków zaproponowanych przez wnioskodawców w projekcie zmiany ustawy o samorządzie gminy warto przywołać ustalenia Trybunału Konstytucyjnego z zakresu zmiany granic gmin.

W pierwszej kolejności należy zwrócić uwagę na postanowienie z 12 maja 2009 r. (sygn. akt S 3/09), w którym Trybunał Konstytucyjny sygnalizował Sejmowi potrzebę stworzenia skutecznych mechanizmów prawnych zabezpieczających jednostki samorządu terytorialnego przed pochopnymi zmianami ich granic. Uzasadnieniem do wydania tego postanowienia sygnalizacyjnego była ocena Trybunału, że wprawdzie przepisy prawne dotyczące zmian granic jednostek samorządu terytorialnego mieszczą się w standardach konstytucyjnych, to jednak sposób ich stosowania wywołuje protesty jednostek samorządu terytorialnego. W opinii Trybunału w związku z powyższym uprawnione jest poszukiwanie takiego modelu przekształceń podziału terytorialnego, który będzie lepiej służył wartościom konstytucyjnym. Zdaniem Trybunału: [w]ydaje się celowe rozważenie nadania rozstrzygnięciom o zmianach podziatu terytorialnego postaci aktów wydawanych przez wojewodów. Akty te mogłyby stanowić przedmiot kontroli sprawowanej przez sądy administracyjne, a jednocześnie Rada Ministrów nie byłaby pozbawiona możliwości wpływania na te rozstrzygnięcia. Zasługuje także na rozważenie poddanie kontroli sądu administracyjnego procesu opiniowania zmian

generalnych i abstrakcyjnych; nie mają więc one charakteru prawotwórczego, nie kreujq norm prawnych i nie sa podstawa ich obowiazywania, a przez ich wydanie dokonuje sie czynności konwencjonalnej (zob. S. Wronkowska, Model rozporzadzenia jako aktu wykonawczego do ustaw w świetle konstytucji i praktyki [w:] Konstytucyjny system źródeł prawa w praktyce, red. A. Szmyt, Warszawa 2005, s. 87 i n.). Zarazem jednak rozporzadzenia te opierają się na Konstytucji i ustawach w sposób, który nie pozwala uznać, że sa pozbawione właściwości aktu normatywnego. Przeciwnie, pierwiastki normatywne tych rozporządzeń wynikaja z normatywności ustaw, których konkretyzacji służa. Maja więc owe rozporządzenia hybrydowy charakter, co nie pozostaje bez konsekwencji dla orzekania o ich zgodności z aktami wyższego rzędu w hierarchii źródeł prawa.

Trybunał Konstytucyjny nie jest powołany do oceny merytorycznej trafności i celowości przyjętych rozwiązań czy też do oceny zasadności polityki rządu $w$ dziedzinie zmian $w$ podziale terytorialnym, jak też do rozstrzygania konkretnych sporów dotyczacych celowości zmian. Czym innym jest kontrola celowości zamierzenia, a czym innym kontrola jego zgodności z Konstytucją. [...] Uznanie, czy pominięto konkretne interesy lokalne, czy dokonane rozstrzygnięcie - oparte na prawie - było właściwe, czy skutki negatywne przeważaja nad pozytywnymi, czy też odwrotnie - pozostaje poza granicami oceny dokonywanej przez Trybunat Konstytucyjny, wyrok TK z 8 kwietnia 2009 r. w sprawie o sygn. akt K $37 / 06$. 
podziału terytorialnego przed wydaniem rozporządzenia przez Radę Ministrów. [...] [P]ożądane byłoby również doskonalenie form współdziałania jednostek samorzadu terytorialnego z organem decydujacym o zmianach granic ich terytorium. Współdziałanie to nie może jednak prowadzić do paraliżu procedury zmian terytorialnych ${ }^{12}$.

W dalszej kolejności z orzecznictwa Trybunału Konstytucyjnego wynika, że:

- Procedura zmian $w$ podziale terytorialnym przewiduje [...] istotne mechanizmy i instytucje gwarancyjne. Polegaja one w szczególności na tym, że wydając na podstawie art. 4 ust. $1 \mathrm{w}$ związku $z$ art. $4 a$ i art. $4 b$ ustawy o samorządzie gminnym rozporządzenie, Rada Ministrów zobowiązana jest do wypetnienia kryteriów odnoszacych się do dyrektyw uwzględniania zintegrowania osadniczo-przestrzennego i społeczno-gospodarczego ustalanego obszaru gminy. Przepisy regulujące procedure wydania rozporzadzenia w sprawie bytu gminy czy jej granic (art. 4a i art. 4b) nakładaja obowiązek konsultacji z mieszkańcami. Ten nakaz ustawowy stanowi realizację zasady wynikajacej $z$ art. 15 ust. 2 Konstytucji, nakazującej uwzględniać więzi społeczne i kulturalne przy tworzeniu zasadniczego podziatu terytorialnego, gdyż daje szansę na wypowiedzenie się przez zainteresowanych ${ }^{13}$.

- Mimo że [...] przepisy prawne [...] przewiduja odpowiednie uczestnictwo $w$ procedurze zmian granic gmin odpowiednich organów samorzadu terytorialnego oraz stosownych konsultacji $z$ mieszkańcami [...] z Rady Ministrów nie zostat zdjęty wynikajacy $z$ art. 4 ust. 1 ustawy o samorzadzie gminnym obowiazek ustalenia granic gmin. Ustawodawca, mając na uwadze [to], że zmiana granic dokonuje się często $w$ warunkach sporu, słusznie [zdecydował o nieprzekazaniu prawa] do ostatecznego ustalenia granic organom samorzadu terytorialnego ${ }^{14}$. Rozwiązanie to służy także zagwarantowaniu praw samorzadu terytorialnego, ponieważ zapobiega niekorzystnym następstwom długotrwałego prowadzenia sporów o kształt podziału terytorialnego ${ }^{15}$.

- W postępowaniu na wniosek zainteresowanej gminy przesłanką skutecznego wszczęcia jest interes publiczny, lecz o wymiarze konkretnie lokalnym - związanym z korektą stosunków terytorialnych, mającą na celu polepszenie sytuacji przynajmniej jednej z gmin.

$W[\ldots]$ postępowaniu [na wniosek zainteresowanej gminy] przesłanka wszczęcia to $z$ reguly polepszenie sytuacji terytorialnej jednej z gmin; choć czasami wnioskować moga o przesunięcie granic obydwie gminy. W tym ostatnim przypadku obie gminy upatruja polepszenia sytuacji w drodze korekty granic. Normalnie jednak chodzi tu o powiększenie jednej gminy kosztem drugiej. Przy-

12 Postanowienie TK z 12 maja 2009 r., sygn. akt S 3/09.

13 Wyrok TK z 8 kwietnia 2009 r., sygn. akt K 37/06.

14 Wyrok TK z 5 listopada 2001 r., sygn. akt U 1/01, OTK ZU 2001, nr 8, poz. 247.

15 Wyrok TK z 8 kwietnia 2009 r., sygn. akt K 37/06. 
czyna wszczynania postępowania $w$ takich razach wiąże się z ocena, czy interes własny tej gminy ma zarazem znamiona lokalnego interesu publicznego, wimie którego warto dokonać zmiany granic, mimo iż prowadzi to do destabilizacji stosunków terytorialnych. Dla oceny, czy interes tej gminy jest publicznym interesem lokalnym, istotne sa następujace czynniki: ocena, czy chodzi o te wzglę$d y$, o których mowa w art. 15 ust. 2 Konstytucji, tj. po pierwsze, polepszenie poprzez taka zmianę więzi społecznych, gospodarczych i kulturalnych oraz po drugie, polepszenie zdolności wykonywania zadań publicznych przez te gmine. Powołać się ona może również uzupetniająco na te względy, o których mowa tylko $w$ art. 4 ust. 3 ustawy, tj. dążenie do zapewnienia jednorodnego układu osadniczego i przestrzennego.

Nie wystarczy jednak samo powołanie się na te względy $i$ ich uzasadnienie (wsparte w przypadku więzi społecznych - wynikami konsultacji). Ocena stanu więzi społecznych mieszkańców obu gmin w relacji do spornego terytorium, choć majaca znaczenie podstawowe $w$ sprawie jest - z natury rzeczy - relatywna.

Nie zawsze także uznane być może za skuteczne powoływanie się przez gmine na istotne trudności lub w ogóle brak zdolności do wykonywania zadań publicznych z powodu braku spornego terytorium. Względy takie, w świetle ustawy, przemawiać mogłyby niekiedy za zniesieniem takiej gminy zamiast za uszczupleniem terytorium innej gminy, czyli w rezultacie ze skutkiem niekorzystnym dla niej. Chodzi o to, żeby powiększenie terytorium tej gminy miało na celu nie tylko polepszenie jej sytuacji, lecz dokonywane było $w$ imię jednej z wartości konstytucyjnie chronionych, a więc takich jak: lepsza realizacja zadań publicznych nałożonych na samorzad przez Konstytucję, lepsze ukształtowanie demokracji lokalnej, więzi międzyludzkich...

Samo jednak stwierdzenie, iż gmina wnioskujaca powołuje się nie tylko na interes własny, lecz i interes publiczny o charakterze lokalnym nie wystarczy jeszcze do uznania go za zasługujący na uwzględnienie przez Radę Ministrów. Musi być brana bowiem pod uwage także sytuacja drugiej gminy, jaka powstałaby po dokonaniu zmian. Sytuacja tej gminy z reguly ulega pogorszeniu, co wynika $z$ istoty tego rodzaju postępowania. Musza jednak istnieć granice tego pogorszenia. Choćby bowiem powiększenie terytorium jednej gminy znajdowało swe uzasadnienie $w$ wartościach konstytucyjnie chronionych - to przecież nie może to prowadzić do unicestwienia tożsamości drugiej gminy. W szczególności, zmiana granic gmin nigdy nie może prowadzić do uniemożliwienia działania drugiej gminy. Byłoby to bowiem w istocie jej faktycznym zniesieniem przy zachowaniu zewnętrznych pozorów utrzymania jej podmiotowości. To zaś kłóciłoby się $z$ istota postępowania $w$ sprawie zmiany granic gmin, nakreślona przez ustawę o samorządzie gminnym.

Istnieją również granice pogarszania jej sytuacji - nawet, jeśli zmiana nie prowadzi do faktycznego, calkowitego zniesienia gminy. Te granice to tak istotne osłabienie więzi międzyludzkich i zdolności do wykonywania zadań publicz- 
nych w gminie, której zabrano część terytorium, że traci ona tożsamość społeczno-polityczna.

Sumując tę część rozważań stwierdzić należy, iż uprawniona - tzn. taka która prowadzić może do zmiany granic gmin, przesłanka wszczęcia postępowania na wniosek zainteresowanej gminy jest publiczny interes lokalny zwiąany z polepszeniem sytuacji społeczno-terytorialnej tej właśnie gminy, a zarazem nie skutkujący uniemożliwieniem lub drastycznym pogorszeniem warunków działania drugiej gminy. Tak więc w postępowaniu tym mamy do czynienia z rozstrzyganiem wielopłaszczyznowego konfliktu interesów. Chodzi bowiem nie tylko o proste przeciwstawienie: wartości konstytucyjnie chronionej, jaka jest stabilizacja stosunków społeczno-terytorialnych kraju - publicznemu interesowi lokalnemu gminy inicjującej postępowanie; $w$ gre wchodzi trzeci czynnik - jest nim ochrona lokalnego interesu publicznego drugiej gminy, której terytorium ma ulec zmniejszeniu. Dopiero jednak po rozstrzygnięciu, czy interes gminy inicjującej postępowanie $w$ ogóle znajduje uzasadnienie w konfrontacji $z$ wartością konstytucyjnie chronioną, jaka jest stabilność granic gmin - Rada Ministrów przejść może do zbadania, czy zmiana taka nie pogorszy drastycznie sytuacji drugiej gminy, znosząc możliwość jej działania lub istotnie ja ograniczając ${ }^{16}$.

- Brak jest podstaw do twierdzenia, że przepisy dotyczące procedury zmiany granic gmin umożliwiaja Radzie Ministrów zmiane granic gminy na korzyść gminy inicjującej postępowanie wbrew stanowisku innych zainteresowanych gmin. Do takiego rozumowania nie dają podstaw przepisy ustawy o samorządzie gminnym, tłumaczone w zgodzie z Konstytucją. Nie wystarczy bowiem sformułowanie przez inicjująca radę wniosku $w$ imię lokalnego interesu publicznego, by zasługiwat on na uwzględnienie przez Radę Ministrów. Wywiedziona musi być skutecznie konieczność dokonania zmiany w konfrontacji z chroniona konstytucyjnie stabilnością granic gmin. Następnie należy wykazać, że zmiana ta - na ogół niekorzystna dla pozostałych gmin - nie doprowadzi do uniemożliwienia wykonywania przez nie zadań publicznych, ani też utraty ich tożsamości społeczno-politycznej. W takich przypadkach mielibyśmy bowiem do czynienia albo z faktycznym zniesieniem tych gmin z powodu calkowitej utraty zdolności do wykonywania zadań publicznych, albo z taka destrukcja więzi społecznych, gospodarczych i kulturowych oraz ograniczeniem zdolności do wykonywania zadań publicznych, która przekreśla sens dalszego, odrębnego ich funkcjonowania ${ }^{17}$.

- Wynik konsultacji, zwłaszcza w postępowaniu wszczynanym na wniosek zainteresowanej gminy, ma znaczenie nie tylko polityczne, ale i prawne - konsultacje sa nieodzowna przesłanka zmian. Wyniki konsultacji odzwierciedlaja nie

16 Wyrok TK z 4 listopada 2003 r., sygn. akt K 1/03.

17 Ibidem. 
tylko stanowisko wspólnot mieszkańców, jeśli chodzi o ocenę działania organów ich „własnych” gmin, ale także stosunek do spornego terytorium. W sprawie spornej między gminami, wynik żadnej z konsultacji nie może mieć bezwzględnie wiążacego charakteru. Nie znaczy to jednak, że wyniki te nie sa znaczace. Oddziałuja one kierunkowo na opinie właściwych rad. Z kolei negatywny wynik konsultacji z mieszkańcami gminy, której dotyczy zmiana granic, zmusza do szczególnego uzasadnienia wniosku gminy inicjującej postępowanie. „Trudno sobie wyobrazić, by konsultacje $w$ tego rodzaju postępowaniu mogły mieć większa doniosłość prawna. Wiążacy charakter konsultacji znosiłby sens postępowania, gdyż prowadziłoby to albo do automatyzmu dokonywania zmian na wniosek jednej rady gminy i jej mieszkańców, albo do uniemożliwienia wszelkich zmian tego rodzaju, w przypadku odmowy ze strony mieszkańców tej gminy, której terytorium ma być zmniejszone ${ }^{18}$.

- Zrozumiały jest [...] niewiążacy charakter konsultacji w przedmiocie zmiany granic gmin (miast). Prawo do konsultacji maja bowiem mieszkańcy obydwu gmin i ich głos musi mieć na równi znaczenie polityczne, zaś interesy mieszkańców w takich razach sa najczęściej sprzeczne, a Radę Ministrów ustawa stawia $w$ roli arbitra. W przypadku gdy postępowanie w sprawie zmiany granic gmin toczy się z inicjatywy zainteresowanej gminy jego skuteczne wszczęcie wymaga w sensie politycznym wsparcia rady gminy przez wole jej mieszkańców. Ta wola rady gminy skonfrontowana być musi z wola mieszkańców drugiej gminy, a $w$ następstwie opiniq rady tamtej gminy. Rada Ministrów rozstrzyga najczęściej zatem konflikt interesów polityczno-terytorialnych dwóch gmin (miast). Wprawdzie możliwe jest sformułowanie przez zainteresowane rady gmin, opinii sprzecznych $z$ wynikami konsultacji, ale łączy się to z odpowiedzialnościa polityczna tych rad przed mieszkańcami w następnych wyborach. Na szczeblu jednostek podstawowych, gdzie mieszkańcy na ogół lepiej się znają, odpowiedzialność ta ma realny wymiar ${ }^{19}$.

- Konstytucyjna zasada współdziałania władz i dialogu społecznego nie oznacza niemożności rozstrzygnięcia sprawy stanowiącej przedmiot debaty czy sporu. To właśnie rozwiązanie problemu jest zarówno celem prowadzenia dialogu, jak $i$ współdziałania władz. Zastosowane w Konstytucji pojęcie „władza” odnosi się do podmiotu dysponującego zdolnością efektywnego działania na podstawie i w granicach prawa. Rozwiązania ustawowe dotyczące dialogu i współdziałania powinny zatem stwarzać przesłanki równoważenia demokratyzmu i efektywności. Mechanizm podejmowania decyzji nie może być jednak tak uksztattowany, by w sytuacji konfliktu była zapewniona przewaga tylko jednej ze stron

18 Zob. Proces prawotwórczy w świetle orzecznictwa Trybunału Konstytucyjnego. Wypowiedzi Trybunału Konstytucyjnego dotyczace zagadnień związanych z procesem legislacyjnym, Trybunał Konstytucyjny, Warszawa 2015, s. 127-128.

19 Wyrok TK z 4 listopada 2003 r., sygn. akt K 1/03. 
albo by Rada Ministrów była pozbawiona zdolności wypełniania nałożonego na niq $w$ art. 146 Konstytucji obowiązku prowadzenia polityki wewnętrznej. Konstytucyjna zasada pomocniczości oznacza, że administracja rządowa podejmuje działania wówczas, gdy mniejsze wspólnoty nie sa w stanie same rozwiązać własnych problemów. Konflikty i różnice interesów będące przesłanka zmian w podziale terytorialnym stanowią przykład sytuacji, w której niezbędne jest działanie centralnego organu państwa, który ma obowiązek dokonania koniecznych zmian $w$ interesie dobra wspólnego ${ }^{20}$.

- Przepisy dotyczące procedury zmiany granic gmin nie przewidują drogi sądowoadministracyjnej ochrony samodzielności jednostek samorządu terytorialnego. Nie ma możliwości zweryfikowania poprawności procesu zmiany granic gmin w postępowaniu sądowym. Niemniej art. 4 ust. 1-3 i art. 4b u.s.g. są zgodne z art. 165 ust. 2 Konstytucji, który przewiduje swego rodzaju domniemanie sądowej ochrony samodzielności jednostek samorządu terytorialnego, gdyż samodzielność jednostek samorządu terytorialnego nie ma charakteru absolutnego. [D]o ustawodawcy należy dostosowanie rozwiązań dotyczacych sadowej ochrony do zakresu samodzielności wynikajacego z konstytucyjnych $i$ ustawowych granic zakresu działania samorzadu. Granica respektowania odrębności interesów wspólnot samorządowych pozostaje dobro wspólne i interes publiczny podlegające ochronie zgodnie z konstytucyjnymi zasadami ustroju państwa. Ustawodawca, stosownie do postanowień ustaw samorządowych, określit role władzy wykonawczej w procesie kształtowania podziatu terytorialnego zgodnie z konstytucyjnie wyznaczonym zakresem właściwości Rady Ministrów. W kompetencjach ustawodawcy jest regulowanie - w granicach odpowiedzialności przed wyborcami - zakresu samodzielnego działania samorzadu terytorialnego $w$ ramach konstytucyjnej zasady jednolitości państwa. Sądowej ochronie może podlegać to, co mieści się w zakresie właściwości samorzadu terytorialnego ukształtowanym $w$ Konstytucji i ustawach. Zakres ten $i$ odpowiadajace mu formy sądowej ochrony - w granicach wyznaczonych przez zasadę jednolitości państwa - moga być poszerzone przez ustawodawce. Trybunał Konstytucyjny jednak nie może tego zakresu kształtować w swoim orzecznictwie ${ }^{21}$.

Zasadność stwierdzenia, że w efekcie zaistniałej sytuacji postanowienia rozporządzeń Rady Ministrów wydawanych na podstawie art. 4 ust. 1 i 2 u.s.g. dotyczące tworzenia, łączenia, dzielenia, znoszenia i ustalania granic gmin wymykają się spod kontroli ich poprawności sprawowanej - jako kontrola konstytucyjności (hierarchicznej zgodności norm) - przez Trybunał Konstytucyjny oraz - jako kontrola sądowoadministracyjna legalności aktów i decyzji administracyjnych - przez sądy administracyjne Trybunał Konstytucyjny

20 Proces prawotwórczy w świetle orzecznictwa Trybunału Konstytucyjnego, op. cit., s. 128.

${ }_{21}$ Wyrok TK z 8 kwietnia 2009 r., sygn. akt K 37/06. 
potwierdził w postanowieniu z 5 listopada 2009 r. (sygn. akt S 6/09). W orzeczeniu tym Trybunał stwierdził, że rozporządzenia Rady Ministrów wydawane w sprawie tworzenia, łączenia, dzielenia, znoszenia i ustalania granic gmin oraz nadawania gminie lub miejscowości statusu miasta i ustalania jego granic: zawieraja postanowienia, które indywidualnie określają konkretna granice pomiędzy sąsiadującymi gminami. W tym aspekcie swej treści postanowienia te maja charakter indywidualny i konkretny, co przesądza o ich odmienności od typowych (klasycznych) unormowań zawartych w aktach normatywnych, których kontrola konstytucyjności została objęta kognicją Trybunału Konstytucyjnego na podstawie art. 188 pkt 1-3 Konstytucji. Postanowienia te materialnie zbliżaja się $w$ swym charakterze prawnym do typowych decyzji administracyjnych (podejmowanych przez organy kolegialne).

W sytuacji, gdy zgodnie z art. 188 pkt 3 Konstytucji przedmiotem kontroli Trybunału Konstytucyjnego są „przepisy prawa”, a więc jednostki tekstu obowiązujących aktów prawnych, noszące cechy normatywności (tj. abstrakcyjności i możliwości wielokrotnego zastosowania), wątpliwa jest dopuszczalność objęcia kontrolą, polegającą na badaniu hierarchicznej zgodności norm, jednostek tekstu aktów pozbawionych atrybutu normatywności, a więc klasycznych cech przepisów prawa.

Prawny wymóg nadania aktom o ustaleniu granic gmin formy rozporządzenia Rady Ministrów sprawia zarazem, że tego typu akty nie podlegają - ze względu na swą formę - kontroli legalności, sprawowanej przez sądy administracyjne (sądy wojewódzkie - w pierwszej instancji i Naczelny Sąd Administracyjny - w drugiej instancji).

Nadto uregulowanie - $w$ formie rozporzadzenia Rady Ministrów w sprawie trybu postępowania przy składaniu wniosków dotyczących tworzenia, łączenia, dzielenia, znoszenia i ustalania granic gmin, nadawania gminie lub miejscowości statusu miasta, ustalania $i$ zmiany nazw gmin $i$ siedzib ich władz oraz dokumentów wymaganych $w$ tych sprawach - szczegółowego trybu postępowania $w$ zakresie określonym nazwa tego rozporzadzenia uniemożliwia kontrole hierarchicznej zgodności rozporządzeń Rady Ministrów wydawanych w konkretnych sprawach ze wskazanym tu rozporządzeniem Rady Ministrów ze względu na formalna równorzędność obu wskazanych aktów prawnych ${ }^{22}$.

Szczególnego znaczenia w kontekście proponowanych zmian legislacyjnych ma także ocena Trybunału Konstytucyjnego materii referendum lokalnego w zakresie, w jakim odnosi się do zmiany granic gmin. W wyroku z 26 lutego 2003 r. (sygn. akt K 30/02 23 ) Trybunał zważył kilka kwestii.

22 Postanowienie TK z 5 listopada 2009 r., sygn. akt S 6/09.

23 OTK-A ZU 2003, nr 2, poz. 16. 
- Artykuł 170 Konstytucji daje prawo społeczności lokalnej do: wypowiadania się bezpośredniego o sprawach dotyczacych tej wspólnoty - czyli o sprawach, które ksztaltuja byt tej wspólnoty i jej tożsamość. Chociaż bowiem zgodnie $z$ art. 16 ust. 1 Konstytucji samorzad istnieje $z$ mocy prawa i wykonuje zadania publiczne $w$ ramach ustaw przesądzających o przystugujacych mu kompetencjach - to jednak ustawodawca nie może tworzyć jednostek samorzadu terytorialnego dowolnie, tzn. bez uwzględnienia więzi społecznych, gospodarczych lub kulturowych, łączących mieszkańców danego terytorium (art. 15 ust. 2 Konstytucji). Maja oni w związku z tym też prawo do niezakłóconego pozostawania $w$ istniejących strukturach terytorialno-politycznych, jeśli akceptuja je, ponieważ respektują wykształcone, zwykle $w$ dtuższym okresie, więzi łączace mieszkańców. Nie oznacza to oczywiście wyłaczenia kompetencji centralnych organów $i$ władz publicznych do decydowania o likwidacji jednostek samorzadu terytorialnego, lecz wskazuje na prawo mieszkańców do oddziatywania na ukształtowanie się decyzji politycznej w tym względzie. Tym samym likwidacja j.s.t. [jednostek samorządu terytorialnego - dopisek M.K.] może następować po zagwarantowaniu niepogorszenia stanu lokalnych więzi społecznych, w efekcie zmiany albo w imię ważnego interesu publicznego, który wymaga zmian nawet kosztem pogorszenia tych więzi. Przesłanka dokonywania takich zmian ze względu na interes publiczny może być zwłaszcza brak zdolności do wykonywania zadań publicznych ${ }^{24}$.

- Ze współistnienia zasady wykonywania zadań samorządowych za pośrednictwem jego organów oraz zasady bezpośredniego wyrażania woli mieszkańców we wszystkich sprawach, które mają decydujące znaczenie dla danej wspólnoty, wynika prawo do wypowiadania się decydującego, tzn. rozstrzygającego daną sprawę co do jej istoty, wyrażonej w pytaniu lub pytaniach referendum i zarazem załatwiającego tę sprawę ostatecznie, ale także prawo współdecydowania, jak i wreszcie - co najmniej - prawo wpływania kształtującego. W grę wchodzi zatem, prawo do wypowiadania się $w$ drodze referendum wiażącego, a następnie opiniodawczego lub konsultacyjnego, czyli takich, które wprawdzie formalnie nie wiąża w sposób zupetny organów, lecz ze względu na swoja wage polityczna i swoja reprezentatywność (powszechność) obliguja pod względem prawnym $w$ ten sposób, iż niezastosowanie się do ważnego i rozstrzygajacego pytania wyniku referendum wymaga podania uzasadnienia. Tak więc - jak to już podkreślat w swoim orzecznictwie TK - także i referendum opiniodawcze, czy konsultacyjne wplywać winno kształtująco na załatwienie sprawy $i$ winno być prawnie - donioste $w$ rozumieniu art. 170 Konstytucji. Tym bardziej, że wynik ważnego referendum jest podawany do wiadomości publicznej, co podnosi walor przejrzystości podejmowanych następnie decyzji politycznych.

24 Wyrok TK z 26 lutego 2003 r., sygn. akt K 30/02. 
- Z art. 170 Konstytucji wynika niewątpliwie, iż wola mieszkańców, którzy uwa$\dot{z} a j a$, iż winni wszyscy wypowiedzieć się w kwestii zmiany granic, podziału lub nawet likwidacji gminy, ma tutaj pierwszeństwo przed wola rady gminy. Jeśli bowiem uznają oni $i w$ sposób prawem przewidziany wyraża wole przeprowadzenia referendum, a sa $w$ całości zainteresowana społecznościa, gdyż taka zmiana dotyka wszystkich mieszkańców, w zakresie łączących ich więzi - to ich żadanie przeprowadzenia referendum jest uprawnione. Ważny wynik takiego referendum winien również podlegać wykonaniu $w$ ten sposób, iż powinien wiązać radę gminy, w zakresie treści sporządzanej przez niq opinii.

- Jest rzecza oczywista, iż sięgnięcie do formy referendum, w zakresie spraw mieszczących się $w$ zadaniach i kompetencjach organów danej jednostki, zwłaszcza, gdy inicjatorem referendum sq organy jednostek samorzadu terytorialnego, winno z natury swojej mieć wiążacy charakter. Organy wspólnoty siegaja bowiem do formy referendum $w$ takich przypadkach, $w$ których sa do jego przeprowadzenia zobligowane ze względu na wage sprawy dla istnienia i rozwoju jednostki lub ze względu na nieusuwalne trudności wyboru najbardziej optymalnego rozwiązania - czyli w sprawach zasadniczych dla danej wspólnoty. Scedowanie decyzji bezpośrednio na mieszkańców winno w takich razach mieć nieodwracalny, a przez to w pelni wiążacy charakter. [...]

W szczególności trzeba wskazać, iż wszędzie tam, gdzie w gre wchodzi tworzenie, łaczenie, podział lub znoszenie jednostek samorzadu terytorialnego a zwłaszcza gmin, a także zmiana ich granic przez centralne organy władz publicznych, które poprzedzone być winno opinia organów stanowiących jednostek dotkniętych zmianami i konsultacjami z mieszkańcami - mieszkańcy maja prawo do wyrażenia swego stanowiska $w$ drodze referendum konsultacyjnego. Wynik takiego referendum wiąże, jeśli chodzi o opinię organów stanowiących odpowiednich jednostek samorzadowych.

Ze względu na trwałe „wpisanie się” instytucji referendum lokalnego w system demokracji lokalnej, prawo do niego przysługuje nie tylko w tych sprawach, które ustawowo sa zastrzeżone dla wiążacego rozstrzygania przez mieszkańców (np. samoopodatkowanie), ale i w takich, gdzie wola mieszkańców współksztattuje sposób zarządzania sprawami dotyczacymi tej wspólnoty. Wynik takiego referendum z formalnoprawnego punktu widzenia nie jest wprawdzie wiążacy, co do sposobu załatwienia sprawy, jednak obliguje organy władz publicznych do określonego zachowania.

- [W] sprawach zastrzeżonych dla władz i organów innych, niż organy tego właśnie samorządu, mieszkańcy nie moga się wypowiadać tak stanowczo, jak w sprawach uznanych przez ustawę za sprawy należace do zakresu zadań danego samorządu. Przemawia za tym wiele względów.

Po pierwsze, mieszkańcy określonej wspólnoty nie moga przyczyniać się w takim samym stopniu kształtująco do rozwiązań normatywnych centralnych władz i organów państwa oraz organów stanowiących innych samorządów, jak moga 
to czynić w odniesieniu do rozwiązań „własnego” prawa lokalnego. Ustanowiony Konstytucja porządek prawny opiera się na zasadzie decentralizacji władzy publicznej (art. 15 ust. 1 Konstytucji), a nie autonomii terytorialnej. Oznacza to, $i \dot{z} w$ zakresie stanowienia prawa lokalnego organy stanowiace jednostek samorzadu terytorialnego spetniaja role uzupełniajaca, wydajac przepisy prawa miejscowego na podstawie $i w$ granicach upoważnienia ustawowego. Tym bardziej, zatem sami mieszkańcy wspólnoty lokalnej nie moga wkraczać w proces legislacyjny w państwie $w$ taki sam sposób, jak to czynią w zakresie stanowienia „własnego" prawa lokalnego.

Po wtóre, niedopuszczalne jest również wkraczanie przez mieszkańców danej wspólnoty $w$ proces stanowienia prawa innej wspólnoty samorządowej, w taki sam sposób jak to czynią w przypadku „własnego” prawa lokalnego. Samorząd terytorialny nie jest zbudowany na zasadzie hierarchiczności. Każdy rodzaj samorzadu, a przez to i kazdy samorzad ma odpowiednie zadania własne. Jeśli zatem mamy do czynienia ze sprawa dotyczaca istotnych interesów danej wspólnoty, która zarazem jest sprawa dotyczaca innej wspólnoty samorzadowej - to proces uzgadniania stanowisk wymaga uregulowania ustawowego. Nie wyłącza to samo przez się możliwości i sensu referendalnej formy wypowiedzi mieszkańców tej pierwszej wspólnoty. Istnieć winna jedynie procedura uzgadniania - bardzo często $w$ takich razach sprzecznych - wyników różnych referendów lokalnych dotyczacych tej samej sprawy. Ta kwestia została jednak całkowicie pominięta przez ustawę o referendum lokalnym; nie reguluja jej też $w$ sposób generalny odpowiednie ustawy samorzadowe. [...]

Wreszcie po trzecie zauważyć należy, że podział na sprawy ogólnokrajowe $i$ lokalne, $w$ tym samorzadów różnych stopni, ma $w$ dużej mierze charakter umowny i zależy od rozstrzygnięć prawa pozytywnego. Prawo to ze względu na umowność podziału musi charakteryzować się dużym stopniem ogólności. Współcześnie bowiem nieomal wszystkie sprawy publiczne mają także swoje aspekty lokalne i wywołuja skutki dotykające określonej społeczności lokalnej. Stąd też kierowanie się wyłącznie brzmieniem art. 170 Konstytucji w oderwaniu od innych jej przepisów mogłoby prowadzić do dezorganizacji procesu stanowienia prawa oraz chaosu. W rezultacie nastąpić mogłoby niezgodne z Konstytucja osłabienie władzy ustawodawczej $i$ w odpowiednim zakresie władzy wykonawczej państwa oraz chaos kompetencyjny między samorządami.

Sumujac, prawo wypowiadania się $w$ drodze referendum lokalnego $w$ materii spraw zastrzeżonych do kompetencji innych władz i organów, aczkolwiek dopuszczalne $i w$ pewnych przypadkach wskazane dla realizacji demokracji $w$ państwie, nie może być traktowane jako zasadnicza, systemowa forma współuczestniczenia $w$ podejmowaniu rozstrzygnięć, znaczacych dla danej wspólnoty ${ }^{25}$.

25 Ibidem. 
Na podstawie powyższych ustaleń dokonanych przez Trybunał Konstytucyjny w okresie, gdy wyrażał on pogląd co do merytorycznej zgodności przepisów dotyczących procedury zmiany granic gmin, można zwrócić uwagę na kilka wątpliwości i pytań, które nasuwają się wobec proponowanych regulacji, a które zostały przedstawione poniżej.

- Związanie Rady Ministrów pozytywną opinią gmin objętych wnioskiem doprowadzi do automatyzmu i pozbawi Radę Ministrów możliwości działania na rzecz rozstrzygnięcia spornej sprawy granic gmin. W praktyce Rada Ministrów przestanie pełnić funkcję arbitra ważącego interesy dwóch stron i dokonującego koniecznych zmian w interesie dobra wspólnego. Sprzyjać to może prowadzeniu długotrwałych sporów o kształt podziału terytorialnego.

- Czy uwarunkowanie działania Rady Ministrów od charakteru opinii gmin objętych wnioskiem nie będzie oznaczało przyznania radom tych gmin, w sposób pośredni, prawa do ostatecznego wpływu na dokonywanie zmian granic? Zgodnie bowiem z propozycją wnioskodawców pozytywna opinia rady gminy objętej wnioskiem jest niezbędna do wydania przez Radę Ministrów rozporządzenia w sprawie zmiany granic gmin na wniosek zainteresowanej rady gminy.

- Czy poprzez związanie Rady Ministrów pozytywną opinią rad gmin objętych wnioskiem mieszkańcy określonej wspólnoty pośrednio nie będą wkraczać w kształtowanie rozwiązań normatywnych Rady Ministrów? Ważny wynik referendum lokalnego będzie bowiem wiązać radę gminy w zakresie treści sporządzanej przez nią opinii, przez co pośrednio będzie również zobowiązywał Radę Ministrów do określonego zachowania. Jeśli w referendum za zaproponowanymi zmianami nie zostanie oddanych więcej niż połowa ważnych głosów, wynik referendum miałby być uważany za negatywną opinię rady gminy, co nie pozwoliłoby Radzie Ministrów wydać stosownego rozporządzenia w sprawie zmian terytorialnych.

- Nie wydaje się, aby proponowane przepisy spełniały postulat równoważnej pozycji obu stron w procedurze dotyczącej zmiany granic. Nawet bowiem jeśli, zgodnie z obiektywną oceną, przesłanką do przeprowadzenia zmiany granic na wniosek zainteresowanej gminy jest publiczny interes lokalny związany z polepszeniem sytuacji społeczno-terytorialnej tej właśnie gminy, a zarazem nieskutkujący uniemożliwieniem lub drastycznym pogorszeniem warunków działania drugiej gminy, to i tak dla możliwości wydania przez Radę Ministrów rozporządzenia w tej sprawie decydujące znaczenie będzie mieć opinia rady gminy, której terytorium miałoby być uszczuplone w procesie zmiany granic.

- Istnieje ryzyko, że nawet jeśli dokonanie zmian granic gmin wynikałoby z zaistnienia dostatecznie ważnej przesłanki, która usprawiedliwiałaby destabilizację stosunków polityczno-terytorialnych, to do zmian może nie dojść z uwagi na domniemanie wyrażenia negatywnej opinii w przypadku niewyrażenia opinii w terminie trzech miesięcy od dnia otrzymania wystąpienia o opinię. Może być bowiem trudne, a nawet w ogóle niemożliwe ze względów formalnych i organizacyjnych przeprowadzenie konsultacji społecznych, w szczególności w postaci referendum w tym terminie. 


\section{Ocena kosztów i korzyści}

\section{Skutki prawne, administracyjne i finansowe}

Można mieć obawy, że proponowane regulacje nie tyle będą miały charakter gwarancyjny dla gmin objętych wnioskiem o zmianę granic, co mogą sprzyjać arbitralności działania organów tych gmin. $\mathrm{W}$ praktyce może również nie działać mechanizm rozstrzygania kolizji pomiędzy publicznym interesem lokalnym gminy inicjującej zmiany terytorialne związanym z polepszeniem jej sytuacji społeczno-terytorialnej a regresją sytuacji gminy tracącej terytorium związaną z pogorszeniem więzi międzyludzkich we wspólnocie oraz zdolności do wykonywania zadań publicznych. W efekcie sprawy sporne o zmiany gmin mogą toczyć się długimi latami. Możliwy będzie paraliż zmiany granic gmin, nawet jeśli w obiektywnej ocenie wniosek zainteresowanej rady gminy w sprawie zmian terytorialnych zasługiwałby na uwzględnienie ze względu na okoliczność jej lokalnego interesu publicznego oraz ograniczony wpływ na pogorszenie sytuacji i możliwości działania drugiej gminy.

Proponowane regulacje nie wywołują bezpośrednich skutków administracyjnych i finansowych, gdyż określają procedurę, według której dokonywane są zmiany terytorialne gmin. Niemniej sam zabieg zmiany granic gmin oznacza zawsze równoczesne zwiększenie i zmniejszenie terytorium. Jedna jednostka samorządu terytorialnego zyskuje tereny atrakcyjne majątkowo kosztem drugiej jednostki, co może wpływać na możliwości budżetowe tych jednostek oraz na ich zdolności wykonywania zadań publicznych.

\section{Skutki społeczne i gospodarcze}

Projektowane zmiany nie powodują bezpośrednich skutków społecznych i gospodarczych natomiast ich pośrednie oddziaływanie wiąże się z efektem samych zmian terytorialnych, których przeprowadzenie określają. Zmiany granic mogą przyczyniać się do podziałów we wspólnocie. Mogą również wpływać na warunki prowadzenia działalności gospodarczej i rozwoju.

W ocenie wnioskodawców proponowane przepisy dadzą obywatelom możliwość aktywnego uczestnictwa w przeprowadzaniu zmian granic gmin inicjowanych przez radę gminy.

\section{Podsumowanie - ogólna ocena projektu}

Na potrzebę stworzenia skutecznych mechanizmów prawnych zabezpieczających jednostki samorządu terytorialnego przed pochopnymi zmianami ich granic ze względu na liczebność protestów tych jednostek wobec zmian terytorialnych wskazywał już Trybunał Konstytucyjny w postanowieniu z 12 maja 2009 r. w sprawie o sygn. akt S 3/09. Stąd m.in. za celowe można uznać wystąpienie 
z propozycją zmiany regulacji ustawowych określających procedurę związaną ze zmianami terytorialnymi gmin. Niemniej środki proponowane przez wnioskodawców mogą budzić wątpliwości, w szczególności w świetle ustaleń dokonanych przez Trybunał Konstytucyjny w okresie, gdy wyrażał pogląd co do merytorycznej zgodności uregulowań w tym zakresie z przepisami konstytucyjnymi. Wydaje się, że kwestię zabezpieczenia interesów gmin w obliczu zmian terytorialnych skuteczniej mogłyby rozwiązać środki pozwalające na zastosowanie drogi sądowej dla ochrony statusu społeczności lokalnej. Propozycje w tym względzie zawiera wspomniane wyżej postanowienie Trybunału Konstytucyjnego.

\section{Bibliografia}

Kubicka-Żac K., Gminy wiejskie oczekuja uregulowania zasad przejmowania ich przez miasta, https://www.prawo.pl/samorzad/zmiana-granic-gmin-i-ustalenie-kwestii-majatkowych-konieczne,374415.html.

Proces prawotwórczy w świetle orzecznictwa Trybunału Konstytucyjnego. Wypowiedzi Trybunatu Konstytucyjnego dotyczace zagadnień zwiazanych $z$ procesem legislacyjnym, Trybunał Konstytucyjny, Warszawa 2015.

Wronkowska S., Model rozporzadzenia jako aktu wykonawczego do ustaw w świetle konstytucji i praktyki [w:] Konstytucyjny system źródeł prawa w praktyce, red. A. Szmyt, Warszawa 2005. 